Article

\title{
Growth and Phenology of Vulpia Myuros in Comparison with Apera Spica-Venti, Alopecurus Myosuroides and Lolium Multiflorum in Monoculture and in Winter Wheat
}

\author{
Muhammad Javaid Akhter $\left.{ }^{1} \mathbb{(}\right)$, Bo Melander $\left.{ }^{1} \mathbb{(}\right)$, Solvejg Kopp Mathiassen ${ }^{1} \mathbb{(}$, \\ Rodrigo Labouriau ${ }^{2}$, Svend Vendelbo Nielsen ${ }^{2}$ and Per Kudsk ${ }^{1, *(B D}$ \\ 1 Department of Agroecology, Research Centre Flakkebjerg, Aarhus University, DK-4200 Slagelse, Denmark; \\ mohammadjaved@agro.au.dk (M.J.A.); bo.melander@agro.au.dk (B.M.); sma@agro.au.dk (S.K.M.) \\ 2 Department of Mathematics, Aarhus University, 8000 Aarhus C, Denmark; \\ rodrigo.labouriau@math.au.dk (R.L.); svn@math.au.dk (S.V.N.) \\ * Correspondence: per.kudsk@agro.au.dk
}

Received: 24 August 2020; Accepted: 3 November 2020; Published: 5 November 2020

\begin{abstract}
Vulpia myuros has become an increasing weed problem in winter cereals in Northern Europe. However, the information about $V$. myuros and its behavior as an arable weed is limited. Field and greenhouse experiments were conducted in 2017/18 and 2018/19, at the Department of Agroecology in Flakkebjerg, Denmark to investigate the emergence, phenological development and growth characteristics of $V$. myuros in monoculture and in mixture with winter wheat, in comparison to Apera spica-venti, Alopecurus myosuroides and Lolium multiflorum. V. myuros emerged earlier than A. myosuroides and A. spica-venti but later than L. multiflorum. Significant differences in phenological development were recorded among the species. Overall phenology of $V$. myuros was more similar to that of L. multiflorum than to A. myosuroides and A. spica-venti. V. myuros started seed shedding earlier than A. spica-venti and L. multiflorum but later than A. myosuroides. V. myuros was more sensitive to winter wheat competition in terms of biomass production and fecundity than the other species. Using a target-neighborhood design, responses of $V$. myuros and A. spica-venti to the increasing density of winter wheat were quantified. At early growth stages "BBCH 26-29", V. myuros was suppressed less than $A$. spica-venti by winter wheat, while opposite responses were seen at later growth stages "BBCH 39-47" and "BBCH 81-90". No significant differences in fecundity characteristics were observed between the two species in response to increasing winter wheat density. The information on the behavior of $V$. myuros gathered by the current study can support the development of effective integrated weed management strategies for $V$. myuros.
\end{abstract}

Keywords: seed shedding; competitive ability; emergence; fecundity; target-neighborhood design; integrated weed management

\section{Introduction}

Noninversion tillage practices have increased throughout Europe in order to preserve soil productivity, reduce labor and costs for fuel among other reasons. Noninversion tillage in combination with a high frequency of winter cereals in the crop rotation has, however, caused new grass weed problems such as Vulpia myuros (L) C.C. Gmel. V. myuros has become an increasing weed problem in winter cereals in Northern Europe [1]. In Denmark, $V$. myuros was first reported in red fescue in the 1990s, and since then the infested area with V. myuros has increased significantly [2]. A more recent survey of grass weeds with a special focus on $V$. myuros revealed the higher infestations of $V$. myuros 
in some parts of Denmark [3]. Within the last 5 years, severe infestations of $V$. myuros have been reported more frequently in winter cereals. V. myuros is also reported in other European countries, for example, in UK, Romania and France, but is still considered a minor weed problem in those countries compared to Denmark [1]. A recent study from Denmark reported that ca. 400 V. myuros plants $/ \mathrm{m}^{2}$ can reduce wheat yield by up to $50 \%$, but ranked $V$. myuros as the least competitive grass weed in winter wheat in comparison with three other important grass species namely Apera spica-venti (L) P. Beauv., Alopecurus myosuroides Huds and Lolium multiflorum Lam [4]. The competitive ability of a weed species mainly depends on time of emergence, plant density and growth and development characteristics [5]. Weed species vary widely in their competitiveness with the crop depending on growth behavior and phenological features such as length of life cycles, initial growth rates, leaf area, root architecture, plant height and reproductive strategies [4,5]. The substantial differences in competitiveness between $V$. myuros, A. spica-venti, A. myosuroides and L. multiflorum could be related to their distinct growth behavior and phenological expressions [6]. A better understanding of the underlying processes that determine differences in competitiveness among these grass species can help develop cost-effective management strategies [7].

Acetolactate synthase (ALS) and acetyl CoA carboxylase (ACCase) inhibitors are the most widely used herbicides to control grass weeds in winter cereals. The natural tolerance in $V$. myuros to most ALS and ACCase inhibitor herbicides is a serious concern to its successful management [8]. Due to unsatisfactory performance of foliar applied herbicides, farmers are dependent on residual herbicides for the control of V. myuros in winter cereals. However, low efficacy of residual herbicides like prosulfocarb and pendimethalin on $V$. myuros is often reported by farmers [1]. Fewer chemical control options mean that integrated weed management (IWM) strategies, built on preventive and cultural methods, need to be adopted in order to manage V. myuros [1]. However, in order to develop effective IWM, basic information about the behavior of $V$. myuros is essential. The information about $V$. myuros and its behavior as an arable weed under Northern European conditions is limited according to a recent review by Akhter et al. [1]. An analysis of growth rate and developmental characteristics permits behavioral analysis of weeds in relation to ecological factors, which provide a useful tool for scheduling weed management tactics $[9,10]$. The primary objective of this study was to assess the emergence, growth and phenology of $V$. myuros in comparison with A. spica-venti, A. myosuroides and L. multiflorum in order to understand the plant traits that classify and determine their competitiveness.

Information on the competitive ability of a weed species at different growth stages is essential for its effective management because it determines the timing and intensity of control needed [8,11]. However, no information is available documenting the interaction of V. myuros with crop at its different growth stages. The secondary objective of this study was, therefore, to study sensitivity of V. myuros to winter wheat competition at different weed growth stages.

\section{Material and Methods}

\subsection{Field Studies}

A total of 2 field experiments were conducted on sandy loam soil at Flakkebjerg, Denmark $\left(55^{\circ} 18^{\prime}\right.$ N $11^{\circ} 23^{\prime}$ E) in 2017/18 and 2018/19. The experimental site has a temperate coastal climate, characterized by mild winters and cool summers. The prevailing climatic conditions were very different across the 2 experiments. A very wet autumn and a dry and warm summer prevailed in the first experiment (October 2017-August 2018) while the weather conditions in the second experiment (September 2018 -August 2019) were closer to normal conditions (Figure 1). 

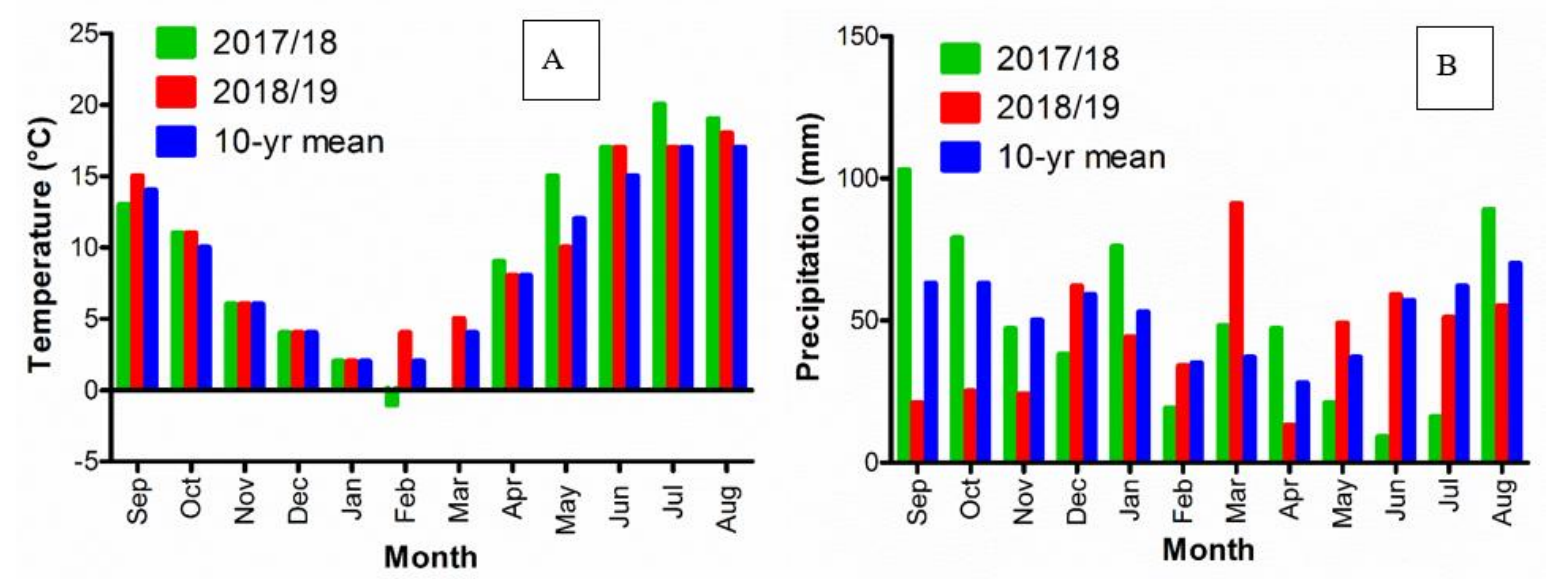

Figure 1. Weather data for 2017/18, 2018/19, and 10 yr means from 2011 to 2020. (A) Monthly average air temperature and $(\mathbf{B})$ precipitation.

The trials were laid out in a randomized complete block design with 3 blocks; net plot size was $2.5 \times 10 \mathrm{~m}$. The experiment had 9 treatments: the 4 grass species grown in monoculture and in mixture with winter wheat, and winter wheat alone. Seeds of the 4 species were collected from a winter wheat field near the experimental site in July 2017, seed samples were stored in paper bags at $4{ }^{\circ} \mathrm{C}$ in the dark until seeding in the field experiments in October 2017 and September 2018. Seeding rates of the grasses were adjusted based on the results of germination tests to achieve a seedling density of 75 plants $\mathrm{m}^{-2}$ both in monoculture and in mixture with winter wheat. Winter wheat (cv. Maribos) was sown at $12.5 \mathrm{~cm}$ row spacing on October 10 in 2017, and September 13 in 2018 and seed rates were adjusted to target a field stand of 350-400 plants $\mathrm{m}^{-2}$. Seeds of grass weed species were drilled at shallow soil depth $(0.5 \mathrm{~cm})$ later on the same day. To obtain enough volume of grass seeds for the drilling operations, grass seeds were mixed with dead seeds of Poa pratensis. Seeds of Poa pratensis were killed by placing them in the oven at $100{ }^{\circ} \mathrm{C}$ for $144 \mathrm{~h}$. In $2017 / 18$, sowing was late due to unusual wet autumn, while crop was sown on time in 2018/19. The field was fertilized in April, with $180 \mathrm{~kg} \mathrm{ha}^{-1}$ nitrogen, $34 \mathrm{~kg} \mathrm{ha}^{-1}$ phosphorus and $86 \mathrm{~kg} \mathrm{ha}^{-1}$ potassium. Broadleaved weeds were controlled in April applying 382.5 $\mathrm{g} \mathrm{ha}^{-1}$ bromoxynil (Buctril EC 225, $225 \mathrm{~g} \mathrm{~L}^{-1}$ bromoxynil, Bayer CropScience) in 2018, and $7.5 \mathrm{~g} \mathrm{ha}^{-1}$ tribenuron-methyl (Trimmer, $500 \mathrm{~g} \mathrm{~kg}^{-1}$ tribenuron-methyl, ADAMA Northern Europe BV) in 2019. Visual observations showed no grass weeds other than those sown in the experimental plots, which otherwise might have influenced the assessments of sown species.

Grass seedlings were counted in April at the tillering stage of the grass weeds in 2 randomly placed $0.25 \mathrm{~m}^{2}$ quadrats per plot in order to determine the grass weed density that had established in spring. To study the cumulative emergence of grasses as a function to thermal time, seedling counts were made in 3 fixed, $0.25 \mathrm{~m}^{2}$, quadrats per plot in the 2017/18 experiment. In 2018/19, counts were only made in 2 fixed, $0.25 \mathrm{~m}^{2}$, quadrats per plot because the results of 2017/18 experiment showed very low variation. Counts were made twice per week in the first 2 weeks after sowing and then biweekly; in total 10 and 6 emergence counts were made in 2017/18 and 2018/19, respectively.

The times needed to reach specific developmental stages of the grasses and the winter wheat were made 17 and 24 times in 2017/18 and 2018/19 respectively, on 5 marked plants of each species per plot, using the $\mathrm{BBCH}$ growth scale from $\mathrm{BBCH} 00$ to $\mathrm{BBCH} 81$ [12]. Plant seedlings emerging on the same date were marked to record the $\mathrm{BBCH}$ growth stages. The same 5 marked plants were used to study the timing of seed shedding using the $\mathrm{BBCH}$ growth scale. An assessment of the time when seeds started to separate "BBCH 93" from the panicles in V. myuros, A. spica-venti, L. multiflorum and seed heads in $A$. myosuroides was also made. This assessment was based on repeated observations that were started after reaching $\mathrm{BBCH} 75$ for each species. Sowing date was used as the reference point for estimating thermal time required to reach key developmental growth stages. 
Weed growth analyses were done 6 times from tillering until maturity by destructive measurements of plant biomass in two $0.25 \mathrm{~m}^{-2}$ quadrates in each plot. At each sampling time, grasses were counted and cut at ground level. Plant material was dried in the oven at $80^{\circ} \mathrm{C}$ for $72 \mathrm{~h}$ to obtain dry matter (DM) content. Biomass was expressed as dry matter per plant to account for any variation in germination.

Germination of $A$. spica-venti was low resulting in much lower densities compared to the other species. Due to small number of plants, the study on A. spica-venti was limited to phenological characteristics only, while for the other species enough plants were present for studying the growth, phenology and fecundity traits as well.

To estimate the potential seed production, 5 plants of each species were collected randomly when $V$. myuros and L. multiflorum panicles, and A. myosuroides heads, had fully developed. Panicle length and head length were measured from the collected plants and numbers of panicles and heads per plant were counted. The correlation between number of seeds per panicle and panicle length and number of seeds per head and head length was used to estimate the seed production per plant as described by Melander [13]. The influence of crop competition on the correlation between seed number per panicle and head length was nonsignificant when comparing with pure stands of the grasses. Therefore, seed production was estimated from correlations based on pooled data of around 30 panicles and heads collected from each species growing in the absence and presence of crop. The estimated $\mathrm{R}^{2}$ values of correlation for $V$. myuros, L. multiflorum and $A$. myosuroides were $0.81,0.71$ and 0.71 , respectively, in 2017/18, and 0.72, 0.63 and 0.75, respectively, in 2018/19 (data not shown).

\subsection{Greenhouse Study}

The target-neighborhood design was used to compare the competitiveness of $V$. myuros and A. spica-venti in response to increasing densities of neighboring winter wheat [14]. Six wheat (cv Maribos) densities of $0,48,96,192,288$ and 576 plants $\mathrm{m}^{-2}$ were established by planting $0,2,4,8,12$ and 24 plants in pots $(23 \mathrm{~cm}$ diameter $\times 30 \mathrm{~cm}$ height) filled with a potting mixture consisting of sandy loam soil, peat and sand (2:1:1). The experiment included 4 factors: 2 grass species, 6 wheat densities, 2 growth stages of winter wheat and 3 harvesting times. The treatments were arranged in a complete randomized design with 4 replicates per treatment, resulting in 288 pots.

A template made of plastic sheet was used to achieve uniform distances between target and neighbor plants, and among neighbor plants [15]. Uniform-sized seeds of V. myuros and A. spica-venti were pregerminated in Petri plates, and transplanted into small paper pots when the leaf coleoptile was $1 \mathrm{~cm}$ long. Following, 1 equally sized weed seedling at the 2-leaf stage was transplanted to the center of each pot when the winter wheat plants were either at the 2 or the 3-4 leaf stage. Additional plants of winter wheat were grown in plastic trays and transplanted at the 2-leaf stage where winter wheat did not germinate or germinated later. The pots were placed in an unheated greenhouse on tables with automatic watering system with natural day length and irradiance reflecting the outdoor conditions. In total, 2 experiments were conducted in parallel with the field experiments; 1 in 2017/18 and 1 in 2018/19.

Above-ground dry matter (DM) of V. myuros and A. spica-venti were measured at "BBCH 26-29" (1st harvest) and "BBCH 39-47" (2nd harvest) of the grasses by cutting plants at the soil surface. In total, 3 replicates per treatment were harvested at each stage. The samples were oven dried for $24 \mathrm{~h}$ at $80^{\circ} \mathrm{C}$ and dry matter (DM) was recorded. The number of tillers per grass plant was counted and plant height was measured. DM of V. myuros and A. spica-venti was also recorded at "BBCH 81-90" (3rd harvest). The seed production of target plants were estimated as described by Melander [13]. The seed production was estimated based on selected counts. The seeds were counted from around 45 panicles, and then lengths of corresponding panicle were measured. These values were used to find a correlation, a function was developed from the correlation and seed production was estimated based on this function. The estimated $\mathrm{R}^{2}$ value of correlation was 0.81 and 0.78 for V. myuros and A. spica-venti, respectively, in 2017 and 0.86 and 0.82, respectively, in 2018. 


\subsection{Data Analysis}

Data from field and greenhouse studies were analyzed year-wise to account for the differences in climatic conditions between 2017/18 and 2018/19 growing seasons.

\subsubsection{Field Studies}

Cumulative emergence of grasses were analyzed using 2-parameter log-logistic Equation (1) as a function of thermal time according to the time to event approach $[16,17]$ :

$$
E(t)=\frac{1}{1+\exp [b(\log (t)-\log (\text { GERM50) })]}
$$

where $E$ is the percent cumulative emergence at particular thermal time $(t)$, GERM50 is the thermal time to attain $50 \%$ emergence, and $b$ is the emergence rate. The thermal time required for initiation of emergence (10\% emergence = GERM10), 50\% emergence (GERM50) and end of emergence $(90 \%$ emergence $=$ GERM90) were estimated with $95 \%$ confidence interval.

In total, 3 parameter Weibull Equation (2) and log-logistic functions Equation (3) were fitted to biomass data from 2017/18 and 2018/19, respectively, as a function of thermal time [17]:

$$
\begin{gathered}
Y=(d) \exp \{-\exp [c(\log (t)-\log (\text { TIME50) })]\} \\
Y=\frac{d}{1+\exp [c(\log (t)-\log (\text { TIME50) })]}
\end{gathered}
$$

In Equations (2) and (3), $Y$ is biomass accumulation of grasses; $c$ is the rate of biomass production and $d$ is the upper limit indicating total plant biomass. In the log-logistic model, TIME50 is the thermal time $\left({ }^{\circ} \mathrm{C}\right)$ needed to produce $50 \%$ of biomass, while the relation is more indirect for the Weibull function, where the TIME50 value was calculated. Due to different climatic conditions across the 2 growing seasons, different models were fitted to the data from the experiments performed in 2017/18 and 2018/19. The model was checked with lack of fit test ( $p>0.05)$, which showed Equations (2) and (3) could be used to describe the biomass accumulation of the grass species [18]. The sensitivity of grass weed species to winter wheat competition was compared using ratio of total biomass production $d$ between grass species grew in the presence and absence of winter wheat competition. The parameter estimates were compared using a post hoc- $t$ test.

The time to reach 6 developmental stages of grass weeds and crop from " $\mathrm{BBCH} 00$ " (sowing) to "BBCH 13" (3rd leaf enfolded), "BBCH 21" (1st side shoot visible), "BBCH 31" (beginning of elongation), "BBCH 51" (beginning of earing), "BBCH 81" (beginning of seed ripening) and "BBCH 93" (seed shedding) was estimated based on the thermal time scale. The statistical analyses were done separately for each growth stage. We compared the mean thermal times between species using a Monte Carlo permutation test (1000 random permutations). The growth stages were recorded at fixed time points, so the exact time when any plant reached a particular stage is unknown. We only had information on the intervals in which specific growth stages were reached. A standard procedure would be to select a point within each interval and use those as if they were the exact times but because each interval covered a range of growth stages, conclusions would depend heavily on the selected points. Instead, to avoid having to select points, we integrated out all possible exact times using Monte Carlo techniques. In each Monte Carlo iteration of the permutation test, we simulated an exact time for every observation assuming that every time point was uniformly distributed in the corresponding time interval. The variability of the estimates of thermal times was characterized by confidence interval (95\% coverage) obtained using non-parametric bootstraps. The data on seed production was analyzed using a permutation test (with 1000 random permutations) combined with nonparametric bootstrap-based confidence intervals ( $95 \%$ coverage, 10,000 bootstrap samples). The suppression in seed production in grasses due to winter wheat competition was demonstrated calculating ratios of 
grass's seed production in the presence and absence of winter wheat. The R-package postHoc [19] was used to perform post-hoc analyses involving the permutation tests.

The thermal time $\left({ }^{\circ} \mathrm{C}\right)$ needed to estimate cumulative emergence of species was calculated using soil temperature, while thermal time required to estimate the $\mathrm{BBCH}$ growth stages and biomass production was calculated using air temperature. The base temperature was set to $1{ }^{\circ} \mathrm{C}$ for both grasses and winter wheat Equation (4) similar to previous studies [20-23]. If the mean temperature was at or below the base temperature, then thermal time values were assumed to be zero.

$$
\text { Thermal time }\left({ }^{\circ} \mathrm{C}\right)=\sum\left\{\left[\frac{\text { Maximum Daily Temperature }+ \text { Minimum Daily temperature }}{2}\right]-1\right\}
$$

\subsubsection{Greenhouse Study}

A 2 parametric nonlinear hyperbolic model was used to analyze the data from the target neighborhood experiment [17]:

$$
\mathrm{Y}=\frac{a}{1+[x / \text { DENS50 }]}
$$

where $\mathrm{Y}$ is response variable (dry biomass, and potential seed production), $x$ denotes wheat density (plant $\mathrm{m}^{-2}$ ), $a$ is the response of target plant growing alone, DENS50 is the effective density of winter wheat reducing response of target plant by $50 \%$. The competitiveness of 2 grass weeds and 2 winter wheat growth stages were compared in terms of the parameter DENS50 by means of a post-hoc test.

All the analyses were performed using the software R (R Foundation for Statistical Computing, Vienna, Austria, http://R-project.org). Time to event and dose response analysis were performed with R package 'drc' [18].

\section{Results}

\subsection{Field Studies}

\subsubsection{Weed Density}

On average, plant population densities of $V$. myuros, L. multiflorum, A. myosuroides and A. spica-venti in the absence and presence of the winter wheat were $57,68,39,10$ and $44,59,19,11$ plants $\mathrm{m}^{-2}$, respectively, in 2017/18 and 64, 85, 57, 19 and 60, 73, 47, 16 plants $\mathrm{m}^{-2}$, respectively, in 2018/19. With one exception, the densities of grasses growing in the absence and presence of winter wheat were not significantly different $(p>0.05)$, therefore growth curves and fecundity characteristics were compared within grass species growing in the absence and presence of crop. In 2017/18, the density of A. myosuroides was significantly lower in the presence of the winter wheat than with no winter wheat.

\subsubsection{Cumulative Emergence}

The cumulative emergence of the grasses in 2017/18 and 2018/19 as a function of thermal time are shown in Figure 2 and regression parameter estimates according to Equation (1) are presented in the Table 1. There were no significant differences in emergence whether grasses emerged alone or in a crop, therefore, regression estimates were compared among grasses ignoring the presence of the winter wheat (Table 1; Figure 2). 

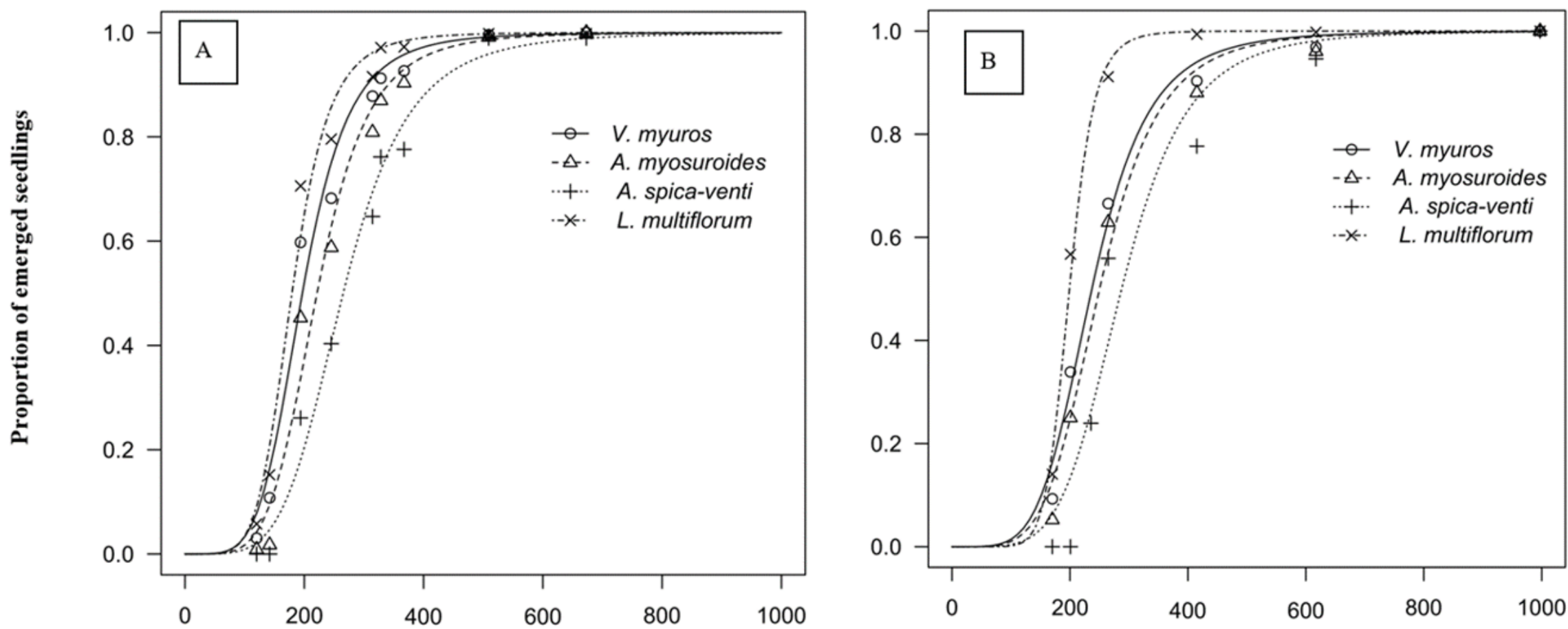

Thermal time $\left({ }^{\circ} \mathrm{C}\right)$

Figure 2. Cumulative emergence dynamics of grass species as a function of thermal time $\left({ }^{\circ} \mathrm{C}\right)$ in $2017 / 18($ A) and 2018/19 (B). Regression equation and parameter estimates given in Table 1. 
Table 1. Regression parameter estimates from log-logistic model Equation (1) for cumulative percent emergence of grass weeds in 2017/18 and 2018/19.

\begin{tabular}{|c|c|c|c|c|c|c|c|c|}
\hline & \multicolumn{8}{|c|}{ Regression Parameters ${ }^{a}$} \\
\hline & \multicolumn{2}{|c|}{$b(95 \% \mathrm{CI})^{\mathrm{c}}$} & \multicolumn{2}{|c|}{ GERM10 $\left({ }^{\circ} \mathrm{C}\right)(95 \% \mathrm{CI})$} & \multicolumn{2}{|c|}{ GERM50 $\left({ }^{\circ} \mathrm{C}\right)(95 \% \mathrm{CI})$} & \multicolumn{2}{|c|}{ GERM90 $\left({ }^{\circ} \mathrm{C}\right)(95 \% \mathrm{CI})$} \\
\hline & 2017/18 & 2018/19 & 2017/18 & 2018/19 & 2017/18 & 2018/19 & 2017/18 & 2018/19 \\
\hline V. myuros & $-5.0(-5.4,-4.6)(1)$ & $-4.9(-5.3,-4.5)(1)$ & $127(119-134)(1)$ & $152(142-161)(1)$ & $197(189-205)(1)$ & $237(227-247)(1)$ & $305(286-324)(1)$ & $371(347-395)(1)$ \\
\hline L. multiflorum & $-5.7(-6.2,-5.2)(2)$ & $-9.5(-10.4,-8.5)(2)$ & $122(116-128)(2)$ & $158(153-163)(2)$ & $179(173-186)(2)$ & $199(195-203)(2)$ & $263(248-277)(2)$ & $251(242-260)(2)$ \\
\hline A. myosuroides & $-5.0(-5.5,-4.7)(3)$ & $-5.0(-5.4,-4.5)(3)$ & $144(136-151)(3)$ & $161(152-170)(3)$ & $221(212-230)(3)$ & $250(240-260)(3)$ & $340(320-361)(3)$ & $389(364-414)(3)$ \\
\hline A. spica-venti & $-4.8(-5.2,-4.4)(4)$ & $-5.2(-5.6,-4.7)(4)$ & $168(156-178)(4)$ & $188(178-198)(4)$ & $265(254-276)(4)$ & $288(276-299)(4)$ & $418(393-444)(4)$ & $440(412-468)(4)$ \\
\hline \multirow{5}{*}{ Significance levels ${ }^{b}$} & 1 vs. $2, p=0.059$ & 1 vs. $2, p<0.001$ & 1 vs. $2, p=0.350$ & 1 vs. $2, p=0.260$ & 1 vs. $2, p<0.001$ & 1 vs. $2, p<0.001$ & 1 vs. $2, p<0.001$ & 1 vs. $2, p<0.001$ \\
\hline & 1 vs. $3, p=0.778$ & 1 vs. $3, p=0.835$ & 1 vs. $3, p<0.001$ & 1 vs. $3, p=0.166$ & 1 vs. $3, p<0.001$ & 1 vs. $3, p=0.067$ & 1 vs. $3, p=0.017$ & 1 vs. $3, p=0.330$ \\
\hline & 2 vs. $3, p=0.104$ & 2 vs. $3, p<0.001$ & 2 vs. $3, p<0.001$ & 2 vs. $3, p=0.550$ & 2 vs. $3, p<0.001$ & 2 vs. $3, p<0.001$ & 2 vs. $3, p<0.001$ & 2 vs. $3, p<0.001$ \\
\hline & 2 vs. $4, p=0.016$ & 2 vs. $4, p<0.001$ & 2 vs. $4, p<0.001$ & 2 vs. $4, p<0.001$ & 2 vs. $4, p<0.001$ & 2 vs. $4, p<0.001$ & 2 vs. $4, p<0.001$ & 2 vs. $4, p<0.001$ \\
\hline & 3 vs. $4, p=0.424$ & 3 vs. $4, p=0.627$ & 3 vs. $4, p<0.001$ & 3 vs. $4, p<0.001$ & 3 vs. $4, p<0.001$ & 3 vs. $4, p<0.001$ & 3 vs. $4, p<0.001$ & 3 vs. $4, p<0.001$ \\
\hline
\end{tabular}

${ }^{\mathrm{a}} \mathrm{E}(\mathrm{t})=1 /\left(1+\exp [b(\log (\mathrm{t})-\log (\right.$ GERM50) $)])$. $\mathrm{E}$ is the cumulative emergence, GERM50 is the thermal time in needed to attain $50 \%$ emergence and $b$ is the rate of emergence. ${ }^{\mathrm{b}}$ Parameter estimates were compared within a year by t-tests at the $5 \%$ level of significance. ${ }^{c}$ Abbreviations: $b=$ emergence rate; CI $=$ confidence interval; GERM10, GERM50, and GERM90 $=$ thermal time $\left({ }^{\circ} \mathrm{C}\right.$ ) needed for $10 \%, 50 \%$ and $90 \%$ emergence, respectively. 
In 2017/18, emergence of V. myuros and L. multiflorum initiated (GERM10) at the same time (127 and $122{ }^{\circ} \mathrm{C}$, respectively) (Table 1). The GERM10 values for A. myosuroides and A. spica-venti were significantly greater than for $V$. myuros. L. multiflorum was the first species to reach GERM50 $\left(179{ }^{\circ} \mathrm{C}\right)$ and GERM90 $\left(263^{\circ} \mathrm{C}\right)$. V. myuros and A. myosuroides needed significantly longer thermal time than L. multiflorum to reach GERM50 $\left(197\right.$ and $221^{\circ} \mathrm{C}$ ) and GERM90 (305 and $\left.340^{\circ} \mathrm{C}\right)$. The last species to reach GERM50 $\left(265^{\circ} \mathrm{C}\right)$ and GERM90 $\left(418^{\circ} \mathrm{C}\right)$ was A. spica-venti. In 2018/19, the GERM10 estimates for V. myuros, L. multiflorum and A. myosuroides were not statistically different. Similar to the previous year, $A$. spica-venti emergence occurred significantly later than the other species. In 2018/19, the overall emergence patterns were very similar to 2017/18, with the same relative differences observed among the grasses (Table 1), though the difference in GERM50 between $V$. myuros and A. myosuroides was nonsignificant.

The emergence rate parameters $(b)$ indicated that $V$. myuros emerged at a similar rate as the other grass weeds. The only exception was in 2018/19, where L. multiflorum emerged significantly more rapidly than the other grass species.

\subsubsection{Phenological Behavior}

There were no significant differences in the phenological development of the grass species or winter wheat grown in monoculture and in mixture with each other $(p>0.05)$. Hence, estimation of thermal time for attaining specific stages of the grasses and winter wheat were made on pooled data (Figure 3; Tables S1 and S2). Winter wheat needed significantly shorter thermal time to reach "BBCH $13^{\prime \prime}$ than the four grasses, for which no differences were found in both growing seasons. Mean thermal time required to attain "BBCH 21" was similar for winter wheat and grasses in 2017/18. However, in 2018/19, winter wheat reached "BBCH 21" first followed by V. myuros, A. myosuroides and L. multiflorum, among which no significant differences were observed. The thermal time for $A$. spica-venti to attain "BBCH 21" was longer than for the other species in 2018/19. A. myosuroides required the shortest thermal time while $A$. spica-venti required the longest thermal time to attain "BBCH 31", "BBCH 50" and "BBCH 81" in both growing seasons. V. myuros attained the "BBCH 31" later than L. multiflorum in both growing seasons and later than winter wheat in 2017/18. There was no significant difference between V. myuros and winter wheat in reaching "BBCH 31" in 2018/19. Thermal time required to achieve "BBCH 51" and "BBCH 81" for V. myuros and L. multiflorum was significantly lower than for winter wheat. The thermal time for V. myuros to attain "BBCH 51" was significantly longer than for L. multiflorum in 2017/18 while no difference was observed in 2018/19. No statistical difference in thermal time to reach "BBCH 81" was found between V. myuros and L. multiflorum in 2017/18 and 2018/19. 


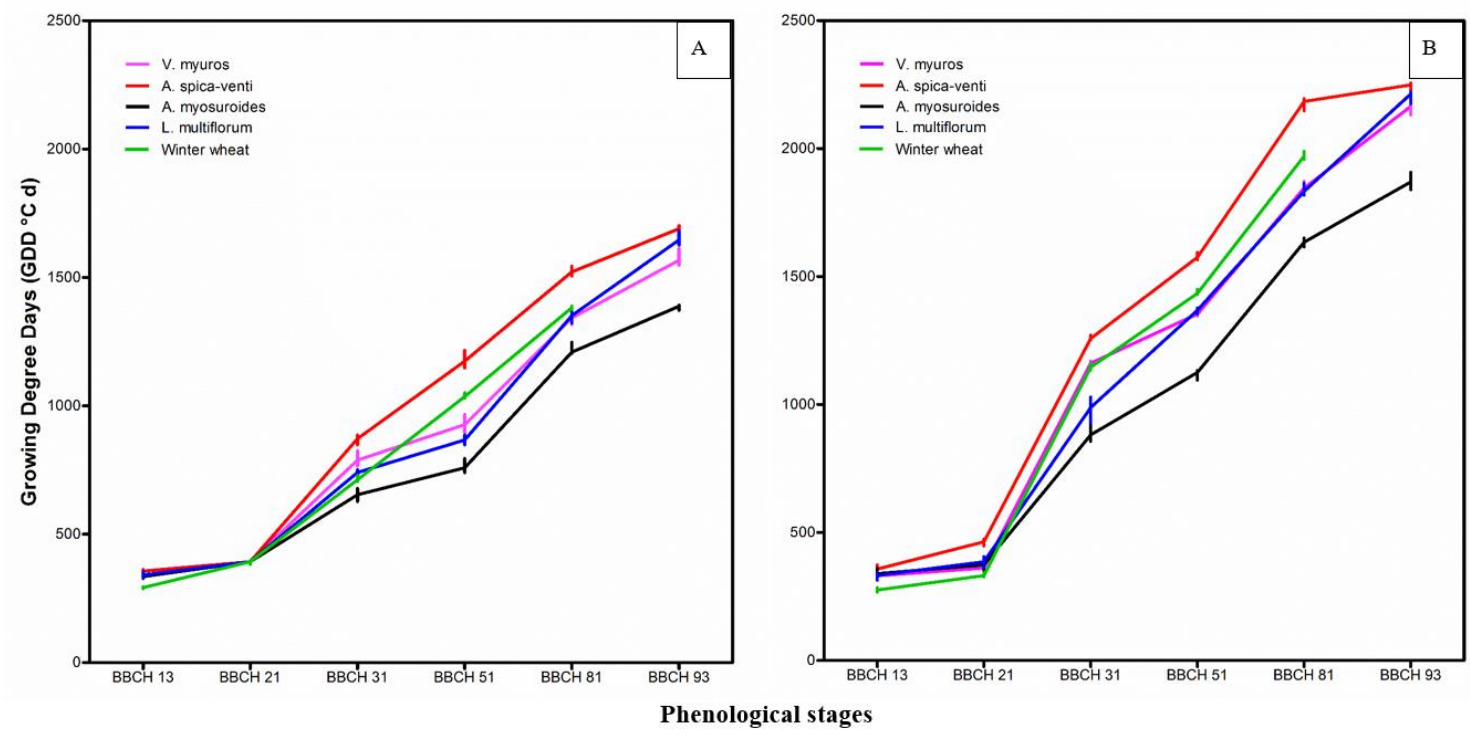

Figure 3. Thermal time $\left({ }^{\circ} \mathrm{C}\right)$ for the grass weeds and winter wheat to reach various phenological stages in 2017/18 (A) and 2018/19 (B). Mean values and 95\% bootstrap confidence intervals are presented in supplementary material (Table S1 (2017/18) and Table S2 (2018/19)).

\subsubsection{Biomass Accumulation}

The biomass accumulation of the grasses in 2017/18 and 2018/19 as a function of thermal time are shown in Figure 4 and regression parameter estimates according to Equation (2) and (3) are presented in the Tables 2 and 3. There were no significant differences in the rate of biomass accumulation (c parameter) and time to accumulate 50\% biomass (TIME50 parameter) between the grasses whether they grew in the absence or presence of winter wheat (Figure 4; Tables 2 and 3), while significant differences were seen in total biomass production ( $d$ parameter). The ratio of total biomass production in the presence and absence of winter wheat varied among the grasses and years. The ratios in total biomass production of $V$. myuros grown in monoculture and with winter wheat were 0.11 and 0.18 in 2017/18 and 2018/19, respectively. The corresponding values for A. myosuroides and L. multiflorum were 0.29 and 0.42 in 2017/18, and 0.32 and 0.68 in 2018/19, respectively. On average, winter wheat suppressed the biomass of $V$. myuros more than of A. myosuroides and L. multiflorum. 

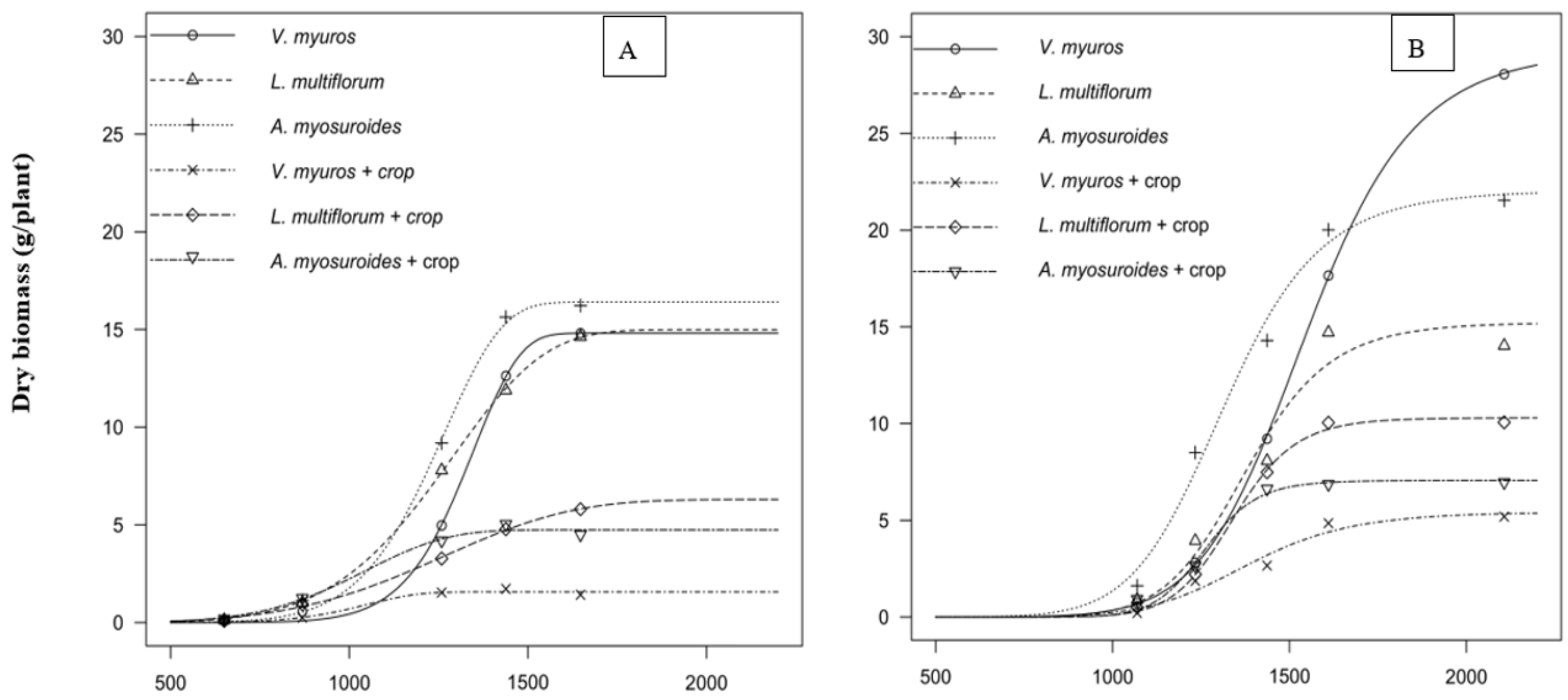

Thermal time $\left({ }^{\circ} \mathrm{C}\right)$

Figure 4. Per plant biomass accumulation of V. myuros, L. multiflorum and A. myosuroides grown in the absence and presence of winter wheat crop in relation to thermal time $\left({ }^{\circ} \mathrm{C}\right)$ in 2017/18 (A) and 2018/19 (B). Regression equation and parameter estimates given in Table $2(2017 / 18)$ and Table 3 (2018/19). 
Table 2. Regression parameter estimates from weibull function Equation (2) fitted to per plant biomass accumulation of grass weeds in the absence and presence of winter wheat in 2017/18. Regression estimates were compared within grasses grown in the absence and presence of winter wheat at the $5 \%$ level of significance. Standard errors are given in parentheses.

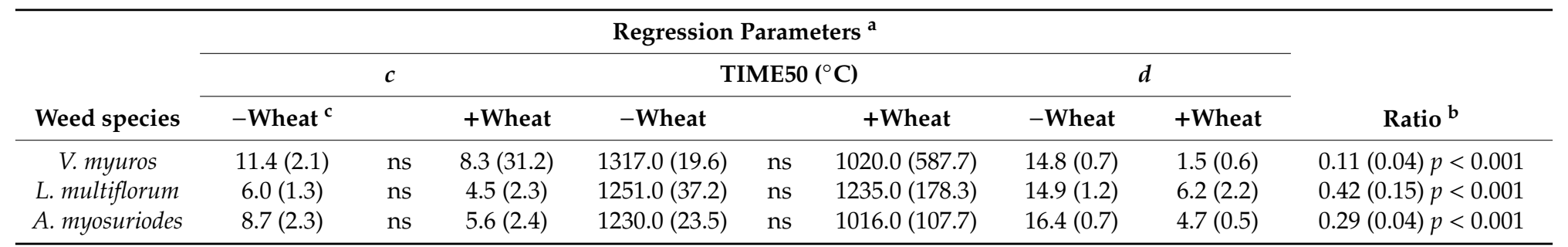

${ }^{\mathrm{a}} \mathrm{Y}=(\mathrm{d}) \exp \left\{-\exp [\mathrm{c}(\log (\mathrm{t})-\log (\right.$ TIME50) $)]\}$ Y is biomass accumulation of grasses; $\mathrm{c}$ is rate of biomass production, TIME50 is the thermal time $\left({ }^{\circ} \mathrm{C}\right)$ needed to produce $50 \%$ of biomass, $d$ is upper limit indicating total plant biomass. ${ }^{\text {b }}$ Estimated ratio in $d$ value at the $5 \%$ level of significance within grass species that grew in the presence and absence of winter wheat. A lower ratio indicates a greater sensitivity of a species to produce biomass with winter wheat competition. ns, nonsignificant (nonsignificant difference within grass species when they grew in the absence and presence of winter wheat). $c$ Abbreviation: -Wheat indicating when grasses grew in the absence of winter wheat; + Wheat indicating when grasses grew in the presence of winter wheat

Table 3. Regression parameter estimates from log-logistic function fitted to per plant biomass accumulation of grass weeds in the absence and presence of winter wheat in 2018/19. Regression estimates were compared within grasses when they were grown in the absence and presence of crop at the $5 \%$ level of significance. Standard errors are given in the parenthesis.

\begin{tabular}{|c|c|c|c|c|c|c|c|c|c|}
\hline \multirow[b]{3}{*}{ Weed species } & \multicolumn{8}{|c|}{ Regression Parameters ${ }^{a}$} & \multirow[b]{3}{*}{ Ratio $^{b}$} \\
\hline & \multicolumn{3}{|c|}{$c$} & \multicolumn{3}{|c|}{ TIME50 $\left({ }^{\circ} \mathrm{C}\right)$} & \multicolumn{2}{|c|}{$d$} & \\
\hline & -Wheat ${ }^{c}$ & & +Wheat & -Wheat & & +Wheat & -Wheat & +Wheat & \\
\hline V. myuros & $-10.1(1.7)$ & ns & $-9.5(5.9)$ & $1548.0(36.5)$ & ns & $1384.0(124.6)$ & $29.3(2.6)$ & $5.4(1.2)$ & $0.18(0.04) p<0.001$ \\
\hline L. multiflorum & $-11.7(2.6)$ & ns & $-15.4(5.5)$ & $1380.0(38.2)$ & ns & $1343.0(44.8)$ & $15.2(1.2)$ & $10.3(1.0)$ & $0.68(0.08) p<0.001$ \\
\hline A. myosuroides & $-9.8(1.7)$ & ns & $-17.3(14.4)$ & $1319.0(34.9)$ & ns & $1263.0(51.7)$ & $22.0(1.6)$ & $7.1(0.9)$ & $0.32(0.05) p<0.001$ \\
\hline
\end{tabular}

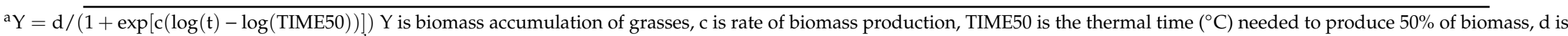
upper limit indicating total plant biomass ${ }^{b}$. Estimated ratio in $d$ value at the $5 \%$ level of significance within grass species that grew in the presence and absence of wheat. A lower ratio indicates a greater sensitivity of a species to produce biomass with winter wheat competition. ns, nonsignificant (nonsignificant difference within grass species when they grew in the absence and presence of wheat). c Abbreviation: -Wheat indicating when grasses grew in the absence of wheat; +Wheat indicating when grasses grew in the presence of wheat. 


\subsubsection{Seed Shedding and Seed Production}

The grass species started seed shedding "BBCH 93" at the same thermal time whether they grew in monoculture or in mixture with a winter wheat crop $(p>0.05)$ (Figure 3; Table S1 and S2). Hence, estimation of time for reaching seed shedding of grasses included data from all plots. Mature seeds of V. myuros, A. spica-venti, A. myosuroides and L. multiflorum started shedding at 1567, 1690, 1387, 1646 and $2165,2249,1870,2213$ thermal time $\left({ }^{\circ} \mathrm{C}\right)$ corresponding to 30 June, 9 July, 19 June, 6 July in 2017/18 and 15 July, 19 July, 25 June, 18 July in 2018/19, respectively. Significant differences were observed among grasses $(p<0.001)$. For instance, $A$. myosuroides started shedding earlier than the other weeds in both years. V. myuros started shedding earlier than L. multiflorum and A. spica-venti, though the difference in relation to L. multiflorum was nonsignificant in 2017/18.

On average, 15,579, 3314 and 8508 seeds plant ${ }^{-1}$ were produced by V. myuros, L. multiflorum and A. myosuroides, in the absence of winter wheat. The presence of winter wheat significantly reduced $(p<0.001)$ seed production in grass species. V. myuros seed production was reduced to a greater extent by the presence of a winter wheat crop than L. multiflorum and A. myosuroides, which responded similarly to crop competition (Table 4). Seed production ratios of grasses grown in the presence and absence of crop competition were significantly lower for V. myuros (0.04 and 0.11 in 2017/18 and 2018/19, respectively) compared to L. multiflorum ( 0.20 and 0.22 in 2017/18 and 2018/19, respectively) and A. myosuroides ( 0.19 and 0.24 in 2017/18 and 2018/19, respectively) (Table 4).

Table 4. Mean per plant seed production and ratio of seed production of annual grass weeds in the presence and absence of winter wheat. For grass species with the same labels (c and d) indicate that the ratio did not differ significantly. $95 \%$ bootstrap confidence intervals are given in parentheses.

\begin{tabular}{|c|c|c|c|c|c|c|}
\hline & \multicolumn{3}{|c|}{$2017 / 18$} & \multicolumn{3}{|c|}{$2018 / 19$} \\
\hline & -Wheat ${ }^{a}$ & +Wheat & ratio $^{b}$ & -Wheat & +Wheat & Ratio \\
\hline V. myuros & 14478 (7833-22715) & $574(472-678)$ & $0.04(0.02-0.07) \mathrm{c}$ & $16680(15019-18446)$ & $1822(1509-2169)$ & 0.11 с $(0.10-0.12)$ \\
\hline L. multiflorum & $2364(2136-2724)$ & $426(339-818)$ & $0.20(0.16-0.25) \mathrm{d}$ & $4264(3691-4774)$ & 958 (752-1158) & $0.22 \mathrm{~d}(0.20-0.24)$ \\
\hline A. myosuroides & $4896(4320-5504)$ & 891 (702-1097) & $0.19(0.14-0.24) \mathrm{d}$ & 12120 (10119-14143) & $2912(2172-3787)$ & $0.24 \mathrm{~d}(0.21-0.27)$ \\
\hline
\end{tabular}

\subsection{Greenhouse Study}

The dry matter (DM) and seed production of V. myuros and A. spica-venti decreased significantly with increasing winter wheat density (Figures S1 and S2). Similar results were observed at both winter wheat growth stages in both years. The average height of $V$. myuros and A. spica-venti plants were $74 \mathrm{~cm}$ and $77 \mathrm{~cm}$ when growing alone, and $117 \mathrm{~cm}$ and $129 \mathrm{~cm}$ when growing at the higher wheat density, respectively. Winter wheat densities above zero had no significant influence on the height of the two grass species.

The effective density of winter wheat (DENS50) reducing the biomass of the target plant by $50 \%$ significantly differed between $V$. myuros and A. spica-venti for the 2-leaf growth stage of winter wheat (Table 5). The greater estimated DENS50 values, the more competitive the weed plant was. At the first harvest "BBCH 26-29", a higher DENS50 value was estimated for V. myuros than for A. spica-venti indicating that $V$. myuros was the most competitive of the two species. Conversely, at the second "BBCH 39-47" and third "BBCH 81-90" harvest times, higher DENS50 values were estimated for A. spica-venti than for $V$. myuros. This response was observed for the 2-leaf stage of winter wheat in both years. The same relative differences were observed for the 3-4 leaf stages of winter wheat; however, these differences were non-significant. 
Table 5. The estimated effective density of winter wheat (DENS50) required to suppress $50 \%$ responses of $V$. myuros and A. spica-venti against increasing winter wheat densities at two different crop growth stages (1-2-leaf stage, 3-4-leaf stage) in 2017/18 and 2018/19 using a target-neighborhood design. Values in parentheses indicate standard errors. DENS50 (winter wheat plants $\mathrm{m}^{-2}$ ) parameter obtained by using two parametric non-linear hyperbolic equation ${ }^{\text {a. }}$

\begin{tabular}{|c|c|c|c|c|c|c|c|c|}
\hline 2017/18 Experiment & & & 1-2-Leaf Stage & & & 3-4-Leaf Stage & & \\
\hline Plant traits & Harvest time & V. myuros (1) & Significance level $^{b}$ & A. spica-venti (2) & V.myuros (3) & Significance level $^{b}$ & A. spica-venti (4) & Significance level $^{\mathrm{c}}$ \\
\hline \multirow{3}{*}{ Biomass } & ВBCH (26-29) & $104(21.0)$ & $p=0.008$ & $35(9.7)$ & $51(25.8)$ & ns & $16(7.2)$ & $\begin{array}{c}1 \text { vs. } 3, p=0.035 \\
2 \text { vs. } 4=\mathrm{ns}\end{array}$ \\
\hline & $\mathrm{BBCH}(39-47)$ & $28(6.1)$ & $p=0.002$ & $92(31.0)$ & 47 (39.3) & ns & $52(23.0)$ & $\begin{array}{l}1 \text { vs. } 3=\mathrm{ns}, \\
2 \text { vs. } 4=\mathrm{ns}\end{array}$ \\
\hline & $\mathrm{BBCH}(81-90)$ & $30(5.6)$ & $p=0.043$ & $82(24.4)$ & $11(3.52)$ & ns & $24(11.7)$ & $\begin{array}{l}1 \text { vs. } 3, p=0.004 \\
2 \text { vs. } 4, p=0.037\end{array}$ \\
\hline $\begin{array}{c}\text { Potential seed } \\
\text { production } \\
\text { 2018/19 experiment }\end{array}$ & $\mathrm{BBCH}(81-90)$ & $39(7.7)$ & ns & $35(8.9)$ & $16(7.39)$ & ns & $20(7.7)$ & $\begin{array}{c}1 \text { vs. } 3, p=0.038 \\
2 \text { vs. } 4=\mathrm{ns}\end{array}$ \\
\hline \multirow{3}{*}{ Biomass } & $\mathrm{BBCH}(26-29)$ & $30(4.0)$ & ns & $17(4.4)$ & $24(10.2)$ & ns & $14(12.7)$ & $\begin{array}{l}1 \text { vs. } 3=\text { ns, } \\
2 \text { vs. } 4=\text { ns }\end{array}$ \\
\hline & $\mathrm{BBCH}(39-47)$ & $10(4.5)$ & $p=0.0013$ & $29(6.8)$ & $9(9.4)$ & ns & $14(7.4)$ & $\begin{array}{l}1 \text { vs. } 3=\mathrm{ns} \\
2 \text { vs. } 4=\mathrm{ns}\end{array}$ \\
\hline & $\mathrm{BBCH}(81-90)$ & $14(5.9)$ & $p<0.001$ & $51(9.2)$ & $7(3.4)$ & ns & $14(4.2)$ & $\begin{aligned} 1 \text { vs. } 3 & =\text { ns, } 2 \text { vs. } 4, \\
p & <0.001\end{aligned}$ \\
\hline $\begin{array}{l}\text { Potential seed } \\
\text { production }\end{array}$ & $\mathrm{BBCH}(81-90)$ & $18(4.6)$ & ns & $43(15.8)$ & $6(2.5)$ & ns & $14(7.8)$ & $\begin{array}{c}1 \text { vs. } 3, p=0.018 \\
2 \text { vs. } 4=\text { ns }\end{array}$ \\
\hline
\end{tabular}
${ }^{\mathrm{a}} \mathrm{Y}=a /(1+[x / \mathrm{DENS50}]) \mathrm{Y}$ is response variable, $x$ denotes wheat density $\left(\right.$ plant $\left.\mathrm{m}^{-2}\right), a$ is the response of target plant growing alone, DENS50 is the effective density of winter wheat
reducing response of target plant by $50 \%$. ${ }^{\mathrm{b}}$ Parameter estimates were compared between species by t-tests at the $5 \%$ level of significance. ${ }^{\mathrm{c}}$ Parameter estimates were compared between

crop growth stages within target plants. ns, nonsignificant difference. 
Generally, the estimated DENS50 values were lower when weeds were transplanted at the 3-4 leaf stage of winter wheat than the 2-leaf stage i.e., the more developed winter wheat plants were more competitive. However, the significant differences between growth stages were inconsistent across harvest times and years for each species. For instance, in 2017/18, the differences between growth stages were only significant for $V$. myuros at the first and third harvest time and for $A$. spica-venti only at the third harvest time. In 2018/19, significant differences were only observed at the third harvest time "BBCH 81-90" and only for A. spica-venti.

At maturity, no significant differences were observed in seed production between $V$. myuros and A. spica-venti grown in competition with winter wheat. Furthermore, a significant difference in seed production between the two winter wheat growth stages were seen in V. myuros, but not in A. spica-venti.

\section{Discussion}

\subsection{Cumulative Emergence}

Our results of $V$. myuros emerging at a similar rate as the other grass weeds are in line with those of Scherner et al. [23,24], who also found no significant differences in the emergence rate $(b)$ between $V$. myuros and A. spica-venti. Regardless of similar emergence rates, the periodicity of emergence differed between $V$. myuros and A. spica-venti. For instance, A. spica-venti initiated emergence (GERM10) later and may therefore require more thermal time to complete the duration of emergence than $V$. myuros. The rapid emergence of $V$. myuros reported here presents an opportunity to control this species though stale or false seed-bed preparation. Preparing a seed-bed but postponing sowing means that many weed seedlings will emerge before crop sowing and can be controlled either chemically or mechanically prior to sowing. A recent study showed that a false seed-bed could reduce the infestation of V. myuros by up to $80 \%$ [25].

Weed and crop emergence time determine the interaction between weed and crop growth [10]. The faster a species emerges, the more it grows at the expense of its competitor [10]. The rapid emergence rate of $V$. myuros indicates the higher early season competitiveness of $V$. myuros compared to A. spica-venti. Akhter et al. [4] demonstrated the potential of $V$. myuros' strong competitive ability with winter wheat early in the growing season. The results highlight the significance of controlling this species early in the growing season.

Under natural conditions, grass weed species have distinct emergence patterns [23]. To include the effect of emergence on weed competitiveness, thermal time required to reach key $\mathrm{BBCH}$ stage was calculated starting on the day of sowing. Germination pattern of dry and newly harvested seeds may deviate from the seeds in the natural soil seedbank. Nondormant seeds in the soil seedbank are already imbibed and ready to germinate immediately after ploughing. This may influence the time of initiation of germination and emergence. Field trials were initiated approximately 4 and 16 months after seed collection in 2017/18 and 2018/19 and seed storage duration and conditions were expected to break primary seed dormancy [24]. Moreover, the relative difference in emergence duration between the species were consistent across years. In addition, the emergence of the four species included in the present study is in accordance with previous studies conducted with a natural soil seed bank under normal growing conditions [23,26-28]. Hence, it can be assumed that seed dormancy did not influence the germination or germination rate in the present study [21,23-25].

\subsection{Growth and Phenology}

Winter wheat, in general, was faster to reach "BBCH 13" and "BBCH 21" than the grass species, which is in accordance with previous findings for A. myosuroides [29]. Sowing of winter wheat later than the optimum time exposed the early plant growth stages to reduced light and temperature conditions that resulted in slower growth and reduced tillering [30-33], which could partially explain the non-significant difference in thermal time among plant species to reach "BBCH 21" in 2017/18 (Figure 3). The information of thermal time needed for leaf and tiller appearance could help optimize 
herbicide application timings and dosages for effective control [20]. Timing of herbicide application is critical because younger weed plants are often more sensitive than more-developed stages [11,34]. This study suggest that early post emergence control of $V$. myuros might be effective up to tillering stage "BBCH 21" of winter wheat because at this stage V. myuros was still at the leaf development stage "BBCH 13" [11]. The study showed that stem elongation "BBCH 31" started earlier in A. myosuroides than in the other grass weed species and wheat. This finding is similar to that by Chauvel et al. [20]. The slower development of $A$. spica-venti started at $\mathrm{BBCH} 21$, and is in accordance with results reported by Soukup et al. [35]. V. myuros and L. multiflorum reached the advanced growth stages "BBCH 51" and "BBCH 80" simultaneously and slower than A. myosuroides but faster than A. spica-venti. Overall, the life cycle of $V$. myuros was more similar to winter wheat and L. multiflorum than to A.myosuroides, which completed its life cycle much faster than winter wheat.

The greater reduction in biomass of $V$. myuros than L. multiflorum and A. myosuroides reflects a higher sensitivity of $V$. myuros to winter wheat competition despite the potential of $V$. myuros to produce more biomass when growing in a pure stands Table 3 . The differences in competitiveness between $V$. myuros and L. multiflorum seems not to be related to their developmental rates but the potential of resource utilization and plant size attributes. V. myuros, probably due to its short stature, shallow root system [36] and low specific area, is less competitive. In contrast, L. multiflorum, due to its deeper roots, higher nutrient uptake, greater stature and high specific leaf area, is highly competitive [37,38]. Weed species with slower developmental rates and longer life cycles are more resource demanding and therefore more competitive, while species with a fast development and short life cycle have shorter time for extraction of resources and, thus, less competitive [9,39]. Due to a slower development, A. spica-venti tends to stay green longer having a higher ability to absorb nutrients from the soil [40]. Because of a short life cycle, A. myosuroides tends to compete with the crop for a shorter duration than A. spica-venti, especially at later crop growth stages [13]. The results from the current study do not allow us to establish any general relationship between weed competitiveness and specific plant traits [7], but the differences can be related to species specific growth and development traits, and periods of active growth [4].

\subsection{Seed Shedding and Seed Production}

V. myuros started seed shedding later than A. myosuroides but earlier than A. spica-venti (Figure 3). The pattern of seed shedding between $V$. myuros and L. multiflorum was inconsistent across the years probably because of different growing conditions between the 2 years (Figure 1). Similar to our results, Bitarafan and Andreasen [41] reported earlier seed shedding in A. myosuroides than A. spica-venti over two growing seasons, and variation in the timing of seed shedding due to different climatic conditions was observed between the years. The percentages of seeds retained on the plants of A. spica-venti and A. myosuroides were $35 \%$ and $34 \%$, respectively, at winter wheat harvest in Denmark [41]. Walsh et al. [42] reported that L. multiflorum retained up to $58 \%$ of the seeds at harvest in US. If seeds retain on the plants, they can be harvested and destroyed which could potentially reduce the soil seedbank markedly over time. The percentages of seed retained on the plants was not measured in the present study. Visual observations showed that a significant proportion of seeds were retained on $V$. myuros at the time of wheat harvest, but the ears were not upright like A. myosuroides, L. multiflorum and A. spica-venti but bending downwards making it less likely that the retained seeds will be collected by the combiner at harvest. There is no published literature reporting the percentage of seeds retained on the V. myuros plant at the time of harvest.

This study explored seed production of four grass weeds growing in monoculture and in competition with winter wheat (Table 4). The presence of a crop canopy can reduce the seed production of weeds by influencing their growth and development [15]. The higher suppression in seed production in V. myuros compared to L. multiflorum and A. myosuroides suggests a potential of suppressing V. myuros by growing competitive crops, which should be considered as part of an IWM strategy. 


\subsection{Greenhouse Study}

The differences in competitiveness of $V$. myuros and $A$. spica-venti recorded in the target-neighborhood experiment can be ascribed to their developmental characteristics as revealed in the field experiments. Faster early growth of $V$. myuros than A. spica-venti makes it a stronger competitor at early growth stages, however, opposite effects were observed at later growth stages. Similar to our results, Dillon and Forcella [10] also noticed a rapid initial growth rate of V. myuros. Although A. spica-venti is less competitive during the early growth stages, its growth rate significantly increases in spring and it can outgrow a crop before heading stage, thus, compete more vigorously with crop at later stages $[13,43]$. The competitive differences of $V$. myuros between early and late growth stages could be due to a more pronounced response to light than $A$. spica-venti, i.e., it is more competitive early in the season where shading by the crop is lower than later in the season when crop canopy is dense. Tozer [36] found that $V$. myuros was a poor competitor for light when growing at high crop densities. $V$. myuros does not grow as high as A. spica-venti and has less specific leaf area [36], which may explain why $V$. myuros is less competitive than A. spica-venti. It was not possible to measure seed production, but the indirect estimation of seed production was a good tool for measuring fecundity traits of grass species [15]. The winter wheat density had less effect on the biomass of $A$. spica-venti than $V$. myuros at maturity; however, the differences in seed production were nonsignificant between the two species. This finding revealed the potential of $V$. myuros to produce enough seeds even with lower accumulated biomass relative to $A$. spica-venti. Nonsignificant differences in numbers of tillers between $V$. myuros and A. spica-venti at maturity is the possible explanation of the nonsignificant difference in the per plant seed production to increasing winter wheat density between the two species. On average, the number of tillers per plant for V. myuros and A. spica-venti at maturity were 22 and 13 growing alone, and 3 and 3 growing at the higher wheat density, respectively. Similarly, to our results Menchari et al. [44] also found a correlation between number of tillers and the total seed production in A. myosuroides.

The results of this study have a direct relevance for understanding not only the features that determine the weedy characteristics of V. myuros but also for devising solutions. Due to natural tolerance to most widely used herbicides, chemical control of $V$. myuros is not highly effective [1]. Hence, farmers are reliant on IWM for reducing the impact of $V$. myuros on crop yield. Information on emergence, life cycle, initial growth rates, patterns of biomass accumulations and seed production potential will help to understand the behavior of $V$. myuros in comparison to the more common grass weed species, A. spica-venti, A. myosuroides and L. multiflorum. The results from this study will provide a scientific basis for developing IWM strategies for V. myuros. Based on this study, V. myuros is classified as less competitive to winter wheat in terms of biomass production and fecundity than the other studied grass weed species. Moreover, our results showed that delayed sowing is an important cultural practice, which provides a window to control the rapid emerging early cohorts of V. myuros mechanically or chemically before sowing. A recent study confirmed the impact of crop competition and delayed sowing in limiting the growth and seed production of V. myuros [4]. Vulpia myuros exhibits phenological traits of a winter annual with a life cycle similar to that of winter wheat, which suggests that inclusion of spring sown in the crop rotation should be effective managing this species. Recently, Scherner et al. [45] have found that the inclusion of spring-sown crops in a 12-year crop rotation dominated by winter cereals significantly suppressed weed seed bank of $V$. myuros, and this effect was more pronounced for $V$. myuros than A. spica-venti. Seed biology studies have revealed that $V$. myuros has lower seed longevity in the soil than other grass species, which is the main reason that infestation of $V$. myuros is mainly associated with noninversion tillage practices $[10,46,47]$. Even though soil cultivation is an effective measure to manage $V$. myuros, no-till is being widely adopted in order to preserve soil productivity. Strategic ploughing, also referred to as occasional ploughing, could be another solution to prevent the build-up of large infestations of V. myuros in no-till systems [1].

Weed population dynamic models can assist in the practical implementation of IWM by predicting long-term effects of different weed management tactics on weed population dynamics [48], and results 
from this study can be employed to parameterize weed population dynamic models in order to predict long-term effects of different control measures on $V$. myuros.

\section{Conclusions}

The results from this study showed that $V$. myuros can emerge fast and exert significant early competition on the crop. The phenology of V. myuros was more similar to that of L. multiflorum and winter wheat than that of $A$. myosuroides and A. spica-venti. Higher sensitivity of $V$. myuros to winter wheat competition in terms of biomass and fecundity suppression suggest that $V$. myuros is the least competitive of the studied grass weed species. The basic information produced in this study adds to the understanding of $V$. myuros behavior as an arable weed. This helps to the formulation and optimization of IWM strategies for the control of V. myuros.

Supplementary Materials: The following are available online at http://www.mdpi.com/2223-7747/9/11/1495/s1, Figure S1: Biomass production of target plants the V. myuros (open markers) and A. spica-venti (filled markers) in response to increasing densities of winter wheat when transplanted at 2-leaf stage (circles) and 3-4 leaf (squares) stages of winter wheat in 2017/18 (A and C) and 2018/19 (B and D). Data from first harvest (A and B) and second harvest (C and D) are shown with fitted curves; Figure S2: Response of target plants the V. myuros (open markers) and $A$. spica-venti (filled markers) with increasing densities of winter wheat when transplanted at 2-leaf stage (circles) and 3-4 leaf (squares) stages of winter wheat in 2017/18 (A and C) and 2018/19 (B and D). Data of biomass production $(A$ and $B)$ and seed production $(C$ and $D)$ are presented at third harvest. Table S1: Estimates and $95 \%$ bootstrap confidence intervals of thermal times $\left({ }^{\circ} \mathrm{C}\right)$ from sowing to various phenological stages for grasses and crop in 2017/18; Table S2: Estimates and 95\% bootstrap confidence intervals of thermal times $\left({ }^{\circ} \mathrm{C}\right)$ from sowing to various phenological stages for grasses and winter wheat in 2018/19.

Author Contributions: Conceptualization, B.M., P.K., S.K.M. and M.J.A.; methodology, M.J.A.; writing-original draft, M.J.A.; writing—review and editing, P.K., B.M., S.K.M., M.J.A., R.L. and S.V.N.; formal analysis, R.L., S.V.N. and M.J.A.; supervision, P.K., B.M. and S.K.M.; project administration, P.K.; funding acquisition, P.K. All authors have read and agreed to the published version of the manuscript.

Funding: Muhammad Javaid Akhter was partially funded by the Graduate School of Science and Technology, Aarhus University, as part of his PhD study, and partially funded by the European Union's Horizon 2020 research and innovation program, under grant agreement No. 727321 (IWMPRAISE).

Acknowledgments: We acknowledge Eugene Driessen, Betina Bendtsen and Christian Nielsen for their skillful technical assistance. We also acknowledge Peter Kryger Jensen for his valuable suggestions on the manuscript.

Conflicts of Interest: The authors declare no conflict of interest.

\section{References}

1. Akhter, M.J.; Jensen, P.K.; Mathiassen, S.K.; Melander, B.; Kudsk, P. Biology and Management of Vulpia myuros-An Emerging Weed Problem in No-Till Cropping Systems in Europe. Plants 2020, 9, 715. [CrossRef]

2. Mathiassen, S.K.; Kudsk, P. Control of Vulpia myuros in red fescue. In Proceedings of the 7th International Herbage Seed Conference, Dallas, TX, USA, 11-14 April 2010; Smith, G.R., Evers, G.W., Nelson, L.R., Eds.; International Herbage Seed Group (IHSG): Dallas, TX, USA, 2010; pp. 136-140.

3. Jensen, P.K.; Kristensen, K. Annual grasses in crop rotations with grass seed production-A survey with special focus on Vulpia spp. in red fescue production. Acta Agric. Scand. Sect. B 2013, 63, 604-611.

4. Akhter, M.J.; Mathiassen, S.K.; Melander, B.; Kudsk, P. Rattail Fescue (Vulpia myuros) Interference and Seed Production as Affected by Sowing Time and Crop Density in Winter Wheat. Weed Sci. 2009, 21, 583-590.

5. Lemerle, D.; Luckett, D.J.; Lockley, P.; Koetz, E.; Wu, H. Competitive ability of Australian canola (Brassica napus) genotypes for weed management. Crop Pasture Sci. 2014, 65, 1300-1310. [CrossRef]

6. Torner, C.; Sanchez, M.J.; Satorre, E.; Fernández-Quintanilla, C. A comparison of the growth patterns and the competitive ability of four annual weeds. Agronomie 2000, 20, 147-156. [CrossRef]

7. Hegazy, A.K.; Fahmy, G.M.; Ali, M.I.; Gomaa, N.H. Growth and phenology of eight common weed species. J. Arid Environ. 2005, 61, 171-183. [CrossRef]

8. Yu, Q.; Shane Friesen, L.J.; Zhang, X.Q.; Powles, S.B. Tolerance to acetolactate synthase and acetyl-coenzyme A carboxylase inhibiting herbicides in Vulpia bromoides is conferred by two co-existing resistance mechanisms. Pestic. Biochem. Physiol. 2004, 78, 21-30. [CrossRef] 
9. Carvalho, L.B.; Bianco, S.; Pitelli, R.A. Growth and mineral nutrition of Ipomoea quamoclit. Planta Daninha 2009, 27, 283-288. [CrossRef]

10. Dillon, S.P.; Forcella, F. Germination, Emergence, Vegetative Growth and Flowering of 2 Silvergrasses, Vulpia-Bromoides (L) Gray, S.F. And Vulpia-Myuros (L) Cc-Gmel. Aust. J. Bot. 1984, 32, 165-175. [CrossRef]

11. Hull, R.; Mathiassen, S.K.; Moss, S.R. Herbicidal control of Vulpia myuros (Rat's-tail fescue) in glasshouse screening tests. Asp. Appl. Biol. 2011, 106, 75-81.

12. Hess, M.; Barralis, G.; Bleiholder, H.; Buhr, L.; Eggers, T.H.; Hack, H.; Stauss, R. Use of the extended BBCH scale-General for the descriptions of the growth stages of mono; and dicotyledonous weed species. Weed Res. 1997, 37, 433-441. [CrossRef]

13. Melander, B. Impact of drilling date on Apera spica-venti L. and Alopecurus myosuroides Huds, in winter cereals. Weed Res. 1995, 35, 157-166. [CrossRef]

14. Swanton, C.J.; Nkoa, R.; Blackshaw, R.E. Experimental methods for crop-weed competition studies. Weed Sci. 2015, 63, 2-11. [CrossRef]

15. Keshtkar, E.; Mathiassen, S.K.; Kudsk, P. No Vegetative and Fecundity Fitness Cost Associated with Acetyl-Coenzyme A Carboxylase Non-target-site Resistance in a Black-Grass (Alopecurus myosuroides Huds) Population. Front. Plant Sci. 2017, 8, 2011. [CrossRef] [PubMed]

16. Ritz, C.; Pipper, C.B.; Streibig, J.C. Analysis of germination data from agricultural experiments. Eur. J. Agron. 2013, 45, 1-6. [CrossRef]

17. Ritz, C.; Baty, F.; Streibig, J.C.; Gerhard, D. Dose-response analysis using R. PLoS ONE 2015, 10, e0146021. [CrossRef] [PubMed]

18. Ritz, C.; Streibig, J.C. Bioassay analysis using R. J. Stat. Softw. 2005, 12, 1-22. [CrossRef]

19. Labouriau, R. postHoc: Tools for Post-Hoc Analysis; Rodrigo Labouriau: Aarhus, Denmark, 2020.

20. Chauvel, B.; Munier-Jolain, N.; Letouzé, A.; Grandgirard, D. Developmental patterns of leaves and tillers in a black-grass population (Alopecurus myosuroides Huds.). Agronomie 2000, 20, 247-257. [CrossRef]

21. Naylor, R. Biological flora of the British Isles. No. 129 Alopecurus myosuroides Huds.(A. agrestis L.). J. Ecol. 1972, 60, 611-622. [CrossRef]

22. Kirby, E.; Appleyard, M.; Fellowes, G. Effect of sowing date and variety on main shoot leaf emergence and number of leaves of barley and wheat. Agronomie 1985, 5, 117-126. [CrossRef]

23. Scherner, A.; Melander, B.; Jensen, P.K.; Kudsk, P.; Avila, L.A. Reducing tillage intensity affects the cumulative emergence dynamics of annual grass weeds in winter cereals. Weed Res. 2017, 57, 314-322. [CrossRef]

24. Scherner, A.; Melander, B.; Jensen, P.K.; Kudsk, P.; Avila, L.A. Germination of winter annual grass weeds under a range of temperatures and water potentials. Weed Sci. 2017, 65, 468-478. [CrossRef]

25. Jensen, P.K. Use of integrated weed management tools in crop rotations with grass seed production. Acta Agric. Scand. Sect. B Soil Plant Sci. 2019, 69, 209-218. [CrossRef]

26. Jensen, P.K. Model for spiring af ukrudtsgræsser. In Anvendelsesorienteret Planteværn 2012; Aarhus Universitet, Institut for Agroøkologi: Aarhus C, Denmark, 2013; pp. 135-139.

27. Wallgren, B.; Avholm, K. Dormancy and germination of Apera spica-venti L. and Alopecurus myosuroides Huds. seeds. Swed. J. Agric. Res. 1978, 8, 11-15.

28. Tribouillois, H.; Dürr, C.; Demilly, D.; Wagner, M.H.; Justes, E. Determination of germination response to temperature and water potential for a wide range of cover crop species and related functional groups. PLoS ONE 2016, 11, e0161185. [CrossRef]

29. Keshtkar, E.; Mathiassen, S.K.; AghaAlikhani, M.; Kudsk, P. Differences in growth, development and innate seed dormancy of susceptible and fenoxaprop-P non-target site resistant black-grass sub-populations. Crop Prot. 2020, 129, 105022. [CrossRef]

30. Friend, D.J.C. Tillering and leaf production in wheat as affected by temperature and light intensity. Can. J. Bot. 1965, 43, 1063-1076. [CrossRef]

31. Hussain, S.; Khaliq, A.; Bajwa, A.; Matloob, A.; Areeb, A.; Ashraf, U.; Hafeez, A.; Imran, M.J.P.D. Crop growth and yield losses in wheat due to little seed canary grass infestation differ with weed densities and changes in environment. Planta Daninha 2017, 35. [CrossRef]

32. Spink, J.H.; Semere, T.; Sparkes, D.L.; Whaley, J.M.; Foulkes, M.J.; Clare, R.W.; Scott, R.K. Effect of sowing date on the optimum plant density of winter wheat. Ann. Appl. Biol. 2000, 137, 179-188. [CrossRef]

33. Fielder, A. Interactions Between Variety and Sowing Date for Winter Wheat and Winter Barley; Home-Grown Cereals Authority: Stoneleigh, UK, 1988. 
34. Kudsk, P. Optimising herbicide performance. In Weed Research: Expanding Horizons Hatcher, 1st ed.; Hatcher, P.E., Froud-Williams, R.J., Eds.; Wiley, Garsington Road: Oxford, UK, 2017; Volume 1, pp. 149-179.

35. Soukup, J.; Novakova, K.; Hamouz, P.; Namestek, J.J.Z. Ecology of silky bent grass (Apera spica-venti (L.) Beauv.), its importance and control in the Czech Republic. J. Plant Dis. Prot. 2006, 20, 73-80.

36. Tozer, K. Ecology and Management of Vulpia spp. G.C. Gmelin in Perennial Pastures of Southern Australia. Ph.D. Thesis, Institute of Land and Food Resources, University of Melbourne, Melbourne, Australia, 2004.

37. Peacock, J.M. Temperature and leaf growth in four grass species. J. Appl. Ecol. 1976, 13, 225-232. [CrossRef]

38. Scursoni, J.A.; Palmano, M.; De Notta, A.; Delfino, D. Italian ryegrass (Lolium multiflorum Lam.) density and $\mathrm{N}$ fertilization on wheat (Triticum aestivum L.) yield in Argentina. Crop Prot. 2012, 32, 36-40. [CrossRef]

39. Barroso, A.; Ferreira, P.; Martins, D.J.P.D. Crescimento e Desenvolvimento de Plantas Daninhas do Gênero Ipomoea. Planta Daninha 2019, 37, e019186421.

40. Gerhards, R.; Massa, D. Zweijährige Untersuchungen mit Herbizidresistenten Populationen von Windhalm (Apera spica-venti L. Beauv.) in Winterweizen-Populationsdynamik, Ertragsverlsute, Bekämpfungserfolg und Auskreuzung der Herbizidresistenz in Sensitive Populationen; 2011 United States Department of Agriculture: Washington, DC, USA; pp. 75-82.

41. Bitarafan, Z.; Andreasen, C. Seed Production and Retention at Maturity of Blackgrass (Alopecurus myosuroides) and Windgrass (Apera spica-venti) at Wheat Harvest. Weed Sci. 2020. [CrossRef]

42. Walsh, M.J.; Broster, J.C.; Schwartz-Lazaro, L.M.; Norsworthy, J.K.; Davis, A.S.; Tidemann, B.D.; Beckie, H.J.; Lyon, D.J.; Soni, N.; Neve, P.J.P.M.S. Opportunities and challenges for harvest weed seed control in global cropping systems. Pest Manag. Sci. 2018, 74, 2235-2245. [CrossRef]

43. Warwick, S.I.; Black, L.D.; Zilkey, B.F. Biology of Canadian Weeds: 72. Apera Spica-Venti. Can. J. Plant Sci. 1985, 65, 711-721. [CrossRef]

44. Menchari, Y.; Chauvel, B.; Darmency, H.; Délye, C. Fitness costs associated with three mutant acetyl-coenzyme A carboxylase alleles endowing herbicide resistance in black-grass Alopecurus myosuroides. J. Appl. Ecol. 2008, 45, 939-947. [CrossRef]

45. Scherner, A.; Melander, B.; Kudsk, P. Vertical distribution and composition of weed seeds within the plough layer after eleven years of contrasting crop rotation and tillage schemes. Soil Till. Res. 2016, 161, 135-142. [CrossRef]

46. Jensen, P.K. Longevity of seeds of four annual grass and two dicotyledon weed species as related to placement in the soil and straw disposal technique. Weed Res. 2009, 49, 592-601. [CrossRef]

47. Jensen, P.K. Longevity of seeds of Poa trivialis and Vulpia myuros as affected by simulated soil tillage practices and straw disposal technique. Grass Forage Sci. 2010, 65, 76-84. [CrossRef]

48. Sønderskov, M.; Somerville, G.J.; Lacoste, M.; Jensen, J.E.; Holst, N. DK-RIM: Assisting Integrated Management of Lolium multiflorum, Italian Ryegrass. Agronomy 2020, 10, 856. [CrossRef]

Publisher's Note: MDPI stays neutral with regard to jurisdictional claims in published maps and institutional affiliations.

(C) 2020 by the authors. Licensee MDPI, Basel, Switzerland. This article is an open access article distributed under the terms and conditions of the Creative Commons Attribution (CC BY) license (http://creativecommons.org/licenses/by/4.0/). 